Fincham, J. R. S. (1954). J. gen. Microbiol. 11, 236-246

\title{
Effects of a Gene Mutation in Neurospora crassa relating to Glutamic Dehydrogenase Formation
}

\author{
By J. R. S. FINCHAM \\ Department of Botany, University of Leicester
}

\begin{abstract}
SUMMARY: Two strains of Neurospora crassa, which require $\alpha$-amino nitrogen for growth as a result of a single gene mutation (am), lack glutamic dehydrogenase. Extracts of mutant mycelium contained no detectable enzyme, although as little as $0.2 \%$ of the amount normally present in the wild type should have been detectable in some experiments. Mutant extracts contained no detectable enzyme inhibitor. A balanced heterocaryon containing am nuclei and nuclei carrying an unrelated mutation produced less enzyme than did wild type mycelium, but there was no indication that the am nuclei were suppressing the activity of the non-am nuclei in promoting enzyme production. The production of the enzyme by the wild type was not strikingly dependent on conditions of growth although the addition of glutamate to the medium seemed somewhat to depress the enzyme concentration. This effect was more marked when glutamate was supplied as a sole nitrogen source. The mutation had little or no effect on the concentrations of two other dehydrogenases or of several transaminases, all related to glutamic dehydrogenase in their substrate specificities. The possible significance of these observations is discussed.
\end{abstract}

A previous paper (Fincham, 1950) reported on mutant strains of Neurospora crassa (No. 32213 and 47305 ) which had a nutritional requirement for $\alpha$-amino nitrogen for growth without a prolonged lag. It was subsequently found (Fincham, 1951 $a$ ) that these mutants apparently lacked glutamic dehydrogenase. Two derivatives of each mutant did not yield detectable amounts of this enzyme in repeated trials, while a number of wild-type strains and mutants of other kinds all gave active enzyme preparations. The fact that any one of a number of different $\alpha$-amino acids will replace glutamic acid in supporting growth is satisfactorily accounted for by the presence of a range of transaminases in $N$. crassa (Fincham, $1951 b$ ).

The experiments reported in this paper were designed to test the previous conclusions by more quantitative measurements of enzyme activity and to gain further information as to the nature of the gene/enzyme relationship.

\section{METHODS}

Chemicals. $\alpha$-Ketoglutaric acid (purchased from British Drug Houses Ltd. or from L. Light and Co.) was recrystallized before use from acetone + benzene (Umbreit, Burris \& Stauffer, 1949). DL-Isocitric acid was obtained from L. Light and Co. and hexose-6-phosphate (c. $70 \%$ glucose- and $30 \%$ fructose-6phosphate) was a gift from Dr B. C. Loughman. Preparations containing coenzyme II (triphosphopyridine nucleotide $=$ TPN) were made from liver according to the method of LePage \& Mueller (1949) up to the stage of chromatographic separation of TPN from DPN. Preparations from beef, pig and sheep liver gave products containing 49, 36 and $31 \%$ TPN respectively; 
the sheep liver preparation was the one used in most of the experiments reported here. Reduced coenzyme II (TPNH) was prepared by reduction with isocitrate and pig heart extract containing isocitric dehydrogenase according to the method of Evans \& Nason (1953), with the modifications that only the empirically determined minimum amount of isocitrate necessary to reduce the TPN was used, and that it was not found necessary to add magnesium ions to obtain adequate activity of the pig heart enzyme. The phosphate buffer referred to throughout this paper was $0.067 \mathrm{~m}$ phosphate at $\mathrm{pH} 7 \cdot 4$ (4) parts $\mathrm{Na}_{2} \mathrm{HPO}_{4}: 1$ part $\mathrm{KH}_{2} \mathrm{PO}_{4}$, B.D.H. Analar grade, in glass-distilled water).

Neurospora strains. The two wild-type strains used in most experiments were 126-1 and 133-2, both of mating-type $A$. These strains, which were used because of their vigour and high fertility, were isolated from experimental crosses in this laboratory by Mr J. A. Pateman. The mutant strain which was used in all the experiments reported here was an albino re-isolate, derived originally from strain 32213, of mating-type $a$ (isolation number 1111-78). This strain will be referred by the gene symbol am (amino-requiring). Two derivatives of am which had recovered the ability to grow normally on minimal medium following ultraviolet irradiation were obtained by Mr Pateman, and were designated UV 17 and UV 21. UV 17 proved to be a heterocaryon containing unchanged am nuclei, and nuclei which were wild-type with respect to the am locus but which had acquired an additional mutation resulting in a requirement for cytidine. Uridine, which would most probably also have been active, was not tested. The new mutation will be given the gene symbol pyr (pyrimidine-requiring). The am and pyr components of the heterocaryon were obtained in homocaryons by isolation of single conidia. UV 21 was also heterocaryotic, containing unchanged $a m$ nuclei, when it was first isolated following irradiation, but it yielded a homocaryotic wild-type back-mutant strain (designated UV 21-W) following isolation of single conidia. The genetic data relating to these back-mutations will be published elsewhere.

Media. For growth of mycelium for enzyme extractions $150 \mathrm{ml}$. lots of liquid medium in bottles giving a depth of medium of $c .1 \mathrm{~cm}$. were used. The usual minimal medium (Fries no. 3) contained, per litre, $5 \mathrm{~g}$. ammonium tartrate; 1 g. $\mathrm{NH}_{4} \mathrm{NO}_{3} ; 1$ g. $\mathrm{KH}_{2} \mathrm{PO}_{4} ; 0.5$ g. $\mathrm{MgSO}_{4} .7 \mathrm{H}_{2} \mathrm{O} ; 0.1 \mathrm{~g} . \mathrm{CaCl}_{2} ; 0.1 \mathrm{~g}$. $\mathrm{NaCl} ; 15$ g. sucrose; $5 \mu \mathrm{g}$. D-biotin; trace elements (Ryan, Beadle \& Tatum, 1943). In experiments where it was desired to vary the nitrogen source without causing wide changes in $\mathrm{pH}$ value a basal $\mathrm{N}$-free buffered medium was used containing, per litre: $5 \mathrm{~g}$. potassium tartrate; $6 \cdot 6 \mathrm{~g}$. $\mathrm{KH}_{2} \mathrm{PO}_{4}+\mathbf{0 . 2 8} \mathrm{g}$. $\mathrm{Na}_{2} \mathrm{HPO}_{4}$ (giving 0.067 $\mathrm{M}$-phosphate, pH 5.6); $\mathrm{MgSO}_{4}, \mathrm{CaCl}_{2}, \mathrm{NaCl}$, trace elements, sucrose and biotin as in ordinary minimal medium. Stock cultures were kept on $1.5 \%$ agar slopes of appropriately supplemented minimal medium.

Preparation of extracts. Mycelium was grown for $48 \mathrm{hr}$. at $25^{\circ}$ without agitation from an inoculum consisting of 0.5-1 ml./bottle of a distinctly turbid suspension of 2- to 4-day old conidia. After washing and pressing out excess moisture (Fincham, 1951 $a$ ) the mycelia usually weighed 1.0-2.5 g. Extraction was carried out by the grinding and filtration procedure previously described 
(Fincham, 1951 $a$ ) or, more conveniently and in all experiments unless otherwise stated, by homogenizing with $100 \mathrm{ml}$. phosphate buffer (pre-chilled to $0-5^{\circ}$ ) for 90 sec. in the monel metal container of an M.S.E. 'Atomix' blender, followed by filtration by suction through a washed pad of $6 \mathrm{~g}$. kieselguhr supported on a filter-paper on a $6 \mathrm{~cm}$. diameter Buchner funnel. Extracts so obtained were free from microscopically visible particles and contained $0.2-0.5 \mathrm{mg}$. protein $/ \mathrm{ml}$.

Protein determinations. Protein of extracts was determined by the following method, based on Stickland (1951). To $5 \mathrm{ml}$. of extract in phosphate buffer, $0.9 \mathrm{ml}$. of $20 \%(\mathrm{w} / \mathrm{v}) \mathrm{NaOH}$ and then $0.15 \mathrm{ml} .25 \%(\mathrm{w} / \mathrm{v}) \mathrm{CuSO}_{4} .5 \mathrm{H}_{2} \mathrm{O}$ was added. The precipitate was broken up with a glass rod and centrifuged after standing for $5 \mathrm{~min}$. The colour in the supernatant was read in an 'Eel' photoelectric colorimeter with a green filter, and was proportional to protein up to at least $1 \mathrm{mg}$. protein/ml., subject to an error of $c .0 .03 \mathrm{mg}$. protein $/ \mathrm{ml}$. Determinations were made in quadruplicate and averaged. The method was standardized against casein and against a preparation of neurospora protein. The colour intensity/mg. protein was the same in both cases.

Enzyme assay procedures. Glutamic dehydrogenase was assayed by following oxidation of TPNH in a Unicam quartz spectrophotometer cell. To a $1 \mathrm{~cm}$. cell was added $1 \mathrm{ml}$. mycelial extract, $5 \mu$ mole (or 6.7 $\mu$ mole in Expts. 4 and 5, Tables 1 and 2) $\mathrm{Na} \alpha$-ketoglutarate, $10 \mu$ mole $\mathrm{NH}_{4} \mathrm{Cl}$, and $1.85 \mathrm{ml}$. phosphate buffer to a total volume of $3 \mathrm{ml}$. The density at wavelength $340 \mathrm{~m} \mu$. was read, and at zero time $\mathbf{0 . 2} \mathbf{m l}$. of a solution of TPNH was added to give an initial increase in optical density of c. $0 \cdot 40$, corresponding to $3 \times 10^{-5} \mathrm{M}-\mathrm{TPNH}$. The optical density was read at 1 min. intervals. The rate of reoxidation of TPNH was constant down to an $E_{340}$ of $c .0 \cdot 25$, and was proportional to enzyme concentration (Fig. 1). Enzyme activity was expressed as change in $E_{340}$ min./mg. protein $\times 10^{3}$. Assays were performed in batches of three, and different batches were not always directly comparable owing to variations in room temperature. By repeating one assay from each batch in the subsequent run, and assuming the same $\boldsymbol{Q}_{10}$ for every digest, assays within a single experiment were made comparable by the use of correction factors generally of the order of $5-15 \%$. Values for enzyme activities from different experiments may not, however, be closely comparable. Room temperatures varied between 17 and $20^{\circ}$.

In some earlier experiments, some of the results of which are referred to in the text, use was made of the fact that neurospora extracts will reduce TPN even when no reducing substrate is added. This is almost certainly due, not to oxidation of an impurity in the coenzyme as previously supposed (Fincham, $1951 a$ ), but to non-dialysable polysaccharide present in the extracts (Tissiéres, Mitchell \& Haskins, 1953). TPN was added to mycelial extract in a spectrophotometer cell, the reduction of TPN followed until the concentration of TPNH remained constant, and then $\alpha$-ketoglutarate and $\mathrm{NH}_{4} \mathrm{Cl}$ were added and the reoxidation rate measured. The disadvantage of this method was that different extracts reduced TPN to different degrees; in some cases the TPN was completely reduced and enough endogenous substrate remained to hinder 
the reoxidation reaction, while in others the TPNH level attained was insufficient for reoxidation to proceed at the maximum rate. The method proved useful as a simple and sensitive qualitative test for the presence or absence of enzyme, and served in favourable instances for quantitative comparisons.

All additions to reaction mixtures were thoroughly mixed in by immediately inverting the cell. Some of the small fluctuations in optical density previously observed following additions to inactive extracts (Fincham, 1951 $a$ ) were probably due to inadequate mixing.

Other determinations. Ammonia was determined by microdistillation followed by nesslerization (Fincham, $1951 a$ ). Glutamic acid was determined in the experiments on transaminases by the method of Fowden (1951), digests being concentrated to one-quarter of their original volume and applied to Whatman no. 3 paper chromatograms as two superimposed $5 \mu \mathrm{l}$. spots.

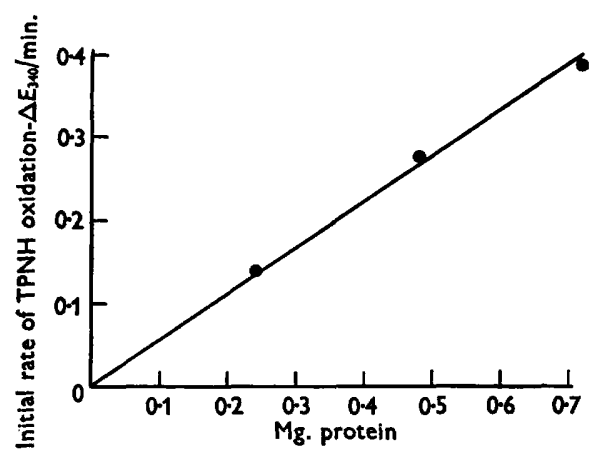

Fig. 1

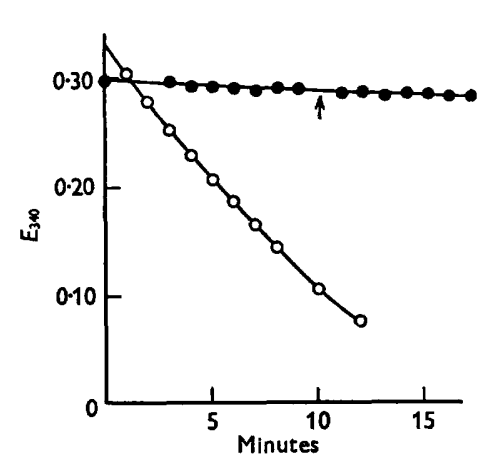

Fig. 2

Fig. 1. Relation between enzyme activity and concentration of protein of extract of wildtype grown on $\mathrm{N}$-free medium $+0.01 \mathrm{~N}$ ammonium tartrate. Data from Expt. 1 (cf. Table 1). Details of assay procedure in the text.

Fig. 2. Reoxidation of TPNH in the standard glutamic dehydrogenase assay system by extract of pyr mycelium, $\mathrm{O}-\mathrm{O}$, containing $0.25 \mathrm{mg}$. protein, compared with the result using extract of am mycelium, - , containing $0.90 \mathrm{mg}$. protein. Data from Expts. 4 and 3 respectively (cf. Table 2 ). In the experiment with pyr $\alpha$-ketoglutarate and $\mathrm{NH}_{4} \mathrm{Cl}$ were present at time 0 ; in the experiment on $\mathrm{am}$ these substrates were added at 10 min. and subsequent readings are corrected for change in vol. $(3 \cdot 2 \rightarrow 3.35 \mathrm{ml}$.) and for $\propto$-ketoglutarate absorption.

\section{RESULTS \\ Absence of enzyme in the mutant}

Fig. 2 shows the results of typical enzyme assays on extracts of mutant and non-mutant mycelium. A very slow decrease in density following addition of TPNH was often observed in experiments on mutant extracts, but this proceeded (Fig. 2) at a rate independent of the presence of $\alpha$-ketoglutarate and ammonia, and was presumably due to a slow destruction of TPNH which had nothing to do with the glutamic dehydrogenase system. This breakdown of TPNH was so slow that it was neglected in computing enzyme activities. In the experiment shown in Fig. 2, $1 \%$ of normal activity in the mutant extract would have been detectable. In other experiments where higher protein 
concentrations were used, more than $\mathbf{0 . 2} \%$ of normal activity in the mutant extract appeared to be excluded.

It has been confirmed that mutant mycelium which had, after a prolonged lag period, acquired a phenotypic adaptation to growth on minimal medium still yielded no detectable glutamic dehydrogenase. The same applies to mutant mycelium which had been grown on minimal medium with the addition of 0.005 M-glutamate. This small concentration of amino acid allowed growth to start without lag and rapidly disappeared from the medium, leaving the mutant mycelium growing solely on inorganic nitrogen. The question of the mechanism of ammonia assimilation under these conditions is an interesting one which has not yet been answered.

\section{Absence of an enzyme inhibitor from mutant extracts}

It was previously reported (Fincham, 1951 $a$ ) that there was no pronounced depression of enzyme activity when mutant extract was added to wild-type extract. This experiment was repeated and the enzyme activities determined more quantitatively. The activity of wild-type extract with and without the addition of an equivalent amount (in terms of protein) of mutant extract was the same to within $3 \%$. It seems clear that the absence of activity of mutant extracts cannot be explained by the presence of a dissociable enzyme inhibitor.

\section{Effect of growth conditions on the activity of wild-type extracts}

A complication which arose in comparing wild type and mutant was that it was difficult to grow the two under identical conditions. The mutant took up ammonia more slowly than the wild type and consequently, in media containing ammonium salts or nitrates (which are reduced to ammonia by neurospora mycelium), the $\mathrm{pH}$ value tended to be higher in cultures of the mutant than with wild type. Thus it was of interest to know how sensitive glutamic dehydrogenase production in the wild type was to alterations in the composition of the medium.

The data shown in Table 1 indicate that the production of the enzyme by wild-type mycelium was not markedly dependent on conditions of growth. Even where glutamic acid was supplied as sole source of nitrogen, under which conditions one might expect glutamic dehydrogenase to be an easily dispensable enzyme and conditions of growth for wild type and mutant should be as closely similar as possible, the concentration of enzyme was still more than $50 \%$ of that found when ammonia was the main nitrogen source in Expts. 4 and 5, although a more striking effect of altering the nitrogen source had been found in Expt. 1. Thus the production of glutamic dehydrogenase is not dependent on the presence of inorganic nitrogen in the medium. The addition of $0.01 \mathrm{M}$-glutamate to the medium had some effect in decreasing the concentration of glutamic dehydrogenase, the decrease being of the order of $30 \%$. This decrease was more marked when glutamic acid was sole nitrogen source. The effect of glutamate on the concentration of glutamic dehydrogenase might provide an explanation for the sparing effect of this substance on 
ammonia uptake (Table 1), which has been observed in a number of experiments apart from those reported here. Possibly parallel instances of a decrease of enzyme concentration in bacteria by the addition to the growth medium of the product of the reaction catalysed by the enzyme in question have been reported by Cohn \& Monod (1953).

Table 1. Production of glutamic dehydrogenase by the wild type grown with various sources of nitrogen

All nitrogen sources were at $0.01 \mathrm{M}$ (or $0.01 \mathrm{~N}$ in case of $\mathrm{NH}_{4}$ tartrate) except the second $\mathrm{NH}_{4}$ tartrate addition in Expt. 5, which was $0.02 \mathrm{~N}$.

\begin{tabular}{|c|c|c|c|c|c|}
\hline Expt. & $\begin{array}{l}\text { Nitrogen } \\
\text { source }\end{array}$ & $\begin{array}{l}\text { Wet wt. } \\
\text { (g.) }\end{array}$ & $\begin{array}{c}\text { Final } \\
\text { pH }\end{array}$ & $\begin{array}{l}\text { Ammonia } \\
\text { used (\%) }\end{array}$ & $\begin{array}{l}\text { Enzyme } \\
\text { activity }\end{array}$ \\
\hline 1 & $\begin{array}{l}\mathrm{KNO}_{3} \\
\mathrm{NH}_{4} \text { tartrate } \\
\text { Glutamic acid* }\end{array}$ & $\begin{array}{l}1 \cdot 3 \\
1 \cdot 9 \\
1 \cdot 5\end{array}$ & $\begin{array}{l}6 \cdot 35 \\
4 \cdot 55 \\
5 \cdot 50\end{array}$ & - & $\begin{array}{l}55 \\
69 \\
13\end{array}$ \\
\hline 4 & $\begin{array}{l}\mathrm{NH}_{4} \text { tartrate } \\
\mathrm{NH}_{4} \text { tartrate }+ \\
\text { glutamic acid* } \\
\text { Glutamic acid* }\end{array}$ & $\begin{array}{l}1 \cdot 5 \\
2 \cdot 1\end{array}$ & $\begin{array}{l}4 \cdot 50 \\
5 \cdot 10\end{array}$ & $\begin{array}{l}93 \\
75\end{array}$ & $\begin{array}{l}74 \\
50\end{array}$ \\
\hline 5 & $\begin{array}{l}\mathrm{NH}_{4} \text { tartrate } \\
\mathrm{NH}_{4} \text { tartrate } \\
\mathrm{NH}_{\text {, tartrate }} \\
\text { glutamic acid* }\end{array}$ & $\begin{array}{l}1 \cdot 5 \\
1 \cdot 55 \\
2 \cdot 55\end{array}$ & $\begin{array}{l}4 \cdot 45 \\
4 \cdot 42 \\
4 \cdot 90\end{array}$ & $\begin{array}{l}93 \\
87 \\
89\end{array}$ & $\begin{array}{r}121 \\
107 \\
82\end{array}$ \\
\hline & $\begin{array}{r}\text { NH }_{\mathbf{4}} \text { tartrate }+ \\
\text { glutamic acid }\end{array}$ & $2 \cdot 0$ & $4 \cdot 66$ & 85 & 60 \\
\hline & $\begin{array}{l}\text { Glutamic acid* } \\
\text { Glutamic acid }\end{array}$ & $\begin{array}{l}1 \cdot 35 \\
0 \cdot 6\end{array}$ & $\begin{array}{l}5 \cdot 45 \\
4.55\end{array}$ & - & $\begin{array}{l}75 \\
45\end{array}$ \\
\hline
\end{tabular}

* Half-neutralized with $\mathrm{NaOH}$.

\section{Production of glutamic dehydrogenase by heterocaryons}

It seemed possible that more information concerning the relation between production of the enzyme and the gene mutation could be obtained by studying enzyme production by heterocaryons carrying varying proportions of $a m$ nuclei. With this end in view the heterocaryon UV $17(a m+p y r)$, which grows like the wild type, was grown on minimal medium, and on minimal medium supplemented with cytidine or glutamate, and the glutamic dehydrogenase activities were compared with the activities in the two homocaryotic derivatives by isolation of single conidia.

To ensure that the mycelium being studied was heterocaryotic, UV 17 cultures were always started from inocula consisting of $0.5 \mathrm{ml}$. of a coarse blend of mycelium prepared as follows. UV 17 conidia were plated on minimal agar and single germinating conidia which showed the wild phenotype were used to inoculate $50 \mathrm{ml}$. minimal medium. After 2-3 days at $25^{\circ}$ the resulting mycelium was washed with sterile distilled water and blended for 30 sec. at half-speed in $100 \mathrm{ml}$. sterile distilled water in a sterilized blender container. If unselected conidia from UV17 cultures had been used as inoculum there would have been danger of overgrowth by one or other type of homocaryon in the supplemented media.

Nuclear ratios in UV 17 cultures were estimated by the following procedure. 
Pads of mycelium ready for enzyme extraction were washed in sterile distilled water, blotted and blended in $100 \mathrm{ml}$. sterile buffer in the sterile blender container at half-speed for $25 \mathrm{sec}$; $\mathbf{0 . 7 5} \mathrm{ml}$. of the coarse blend was then withdrawn aseptically and run on to a 6-day culture of wild type of mating type $A$ growing on a slope of Westergaard \& Mitchell's (1947) crossing medium. The rest of the blend was then further blended for 80 sec. at full speed and filtered to be used for enzyme assay in the usual way. The fertilized cultures discharged ascospores on to the inside of the tube in about 2 weeks. Ascospores were collected from as wide an area as possible, spread on plates of minimal agar, activated by heating for $30 \mathrm{~min}$. at $60^{\circ}$, and left for $16 \mathrm{hr}$. at room temperature. After this time germinating wild-type ascospores with long branching hyphae could be clearly distinguished from pyr spores with very short almost spherical germ tubes, and distinguished with fair certainty from am spores which had thin tapering hyphae of medium length. The two mutant types combined were always essentially equal in number to wild-type ascospores, indicating that there was no differential germination. At least 500 ascospores were counted for each determination. The true values of the ascospore ratio from which the estimated ratio would be just significantly different at the $5 \%$ level can be calculated by means of the $\chi^{2}$ method, and the resulting confidence limits are approximately indicated in Table 2. The actual likely error in the estimate of the nuclear ratio will be greater than thus indicated, since the ascospore ratio is itself only an estimate of the nuclear ratio subject to a sampling error depending on the number of perithecia (probably usually of the order of a few hundred) from which ascospores have been taken. The method did, however, give reasonable results in a reconstruction experiment in which known proportions of am and pyr homocaryotic mycelia were blended together. Blends containing, on a dry weight basis, 20, 57 and $87 \%$ of pyr mycelium gave estimated percentages of pyr nuclei of 15,56 and 84 respectively.

The results of the experiments on the heterocaryon are given in Table 2. Extracts of heterocaryotic mycelium gave consistently less enzyme activity than extracts of the derived pyr homocaryon, which itself gave about the same activity as wild type (it has been shown that the supplementation of minimal medium with cytidine has little or no effect on enzyme level in the wild type). The proportion of normal activity shown by the heterocaryon was, in general, of the same order as the proportion of pyr nuclei, or somewhat greater. In Expt. 4 (Table 2) the concentration of glutamic dehydrogenase was markedly depressed by the supplementation of the medium with glutamate, and a similar, though less striking effect, was shown in Expts. 2 and 3. As already noted, glutamate had a similar effect on the wild type, and the rather larger depression of enzyme level in UV17 in Expt. 4 may have been due to the same cause, perhaps combined with an increase in the proportion of am nuclei in the presence of glutamate. Any such shift in the nuclear ratio was evidently quite small; in fact the nuclear ratio in this heterocaryon in the experiments as a whole showed surprising stability to changes in the composition of the medium. 
The data in Tables 1 and 2 suggest that higher yields of glutamic dehydrogenase were obtained from mycelium grown on the $\mathrm{N}$-free medium supplemented with $0.01 \mathrm{~N}$-ammonium salt than from mycelium grown on the ordinary minimal medium, though the high activities in Expts. 4 and 5 are partly attributable to the slightly higher $\alpha$-ketoglutarate concentration adopted in the assay system in these experiments.

Table 2. Production of glutamic dehydrogenase by the heterocaryon UV17 and derived homocaryons

\begin{tabular}{|c|c|c|c|c|c|}
\hline $\begin{array}{l}\text { Expt. } \\
\text { no. }\end{array}$ & Strain & Medium & $\begin{array}{l}\text { Wet wt. } \\
\text { (g.) }\end{array}$ & $\begin{array}{l}\text { Enzyme } \\
\text { activity }\end{array}$ & $\begin{array}{c}\text { Estimated \% } \\
a m^{+} \text {nuclei }\end{array}$ \\
\hline \multirow[t]{5}{*}{2,3} & pyr & $\begin{array}{l}\text { Minimal + } 0.15 \mathrm{mg} \cdot / \\
\text { ml. cytidine }\end{array}$ & $1 \cdot 55,1 \cdot 5$ & 49,36 & 100 \\
\hline & UV 17 & Minimal & $1 \cdot 15,1 \cdot 6$ & 32, 24 & $54 \pm 8,57 \pm 7$ \\
\hline & UV17 & $\begin{array}{l}\text { Minimal + 0.01 M- } \\
\text { glutamic acid* }\end{array}$ & $1.75,1.95$ & 23,14 & $70 \pm 6,50 \pm 7$ \\
\hline & UV 17 & $\begin{array}{l}\text { Minimal + } 0 \cdot 15 \mathrm{mg} . / \\
\text { ml. cytidine }\end{array}$ & $1 \cdot 55,1 \cdot 5$ & 32, 33 & $71 \pm 8,44 \pm 5$ \\
\hline & $a m$ & $\begin{array}{l}\text { Minimal + 0.01 M- } \\
\text { glutamic acid* }\end{array}$ & $1 \cdot 1,1 \cdot 5$ & 0,0 & $\mathbf{0}$ \\
\hline \multirow[t]{3}{*}{4} & pyr & $\begin{array}{l}\mathrm{N} \text {-free }+0.15 \mathrm{mg} . / \\
\text { ml. cytidine }+ \\
0.01 \mathrm{~N}-\mathrm{NH}_{4} \text { tartrate }\end{array}$ & $\left.\begin{array}{l}1 \cdot 6 \\
1 \cdot 6\end{array}\right\}^{\dagger}$ & $\left.\begin{array}{l}81 \\
91\end{array}\right\}$ & 100 \\
\hline & UV 17 & $\begin{array}{l}\mathrm{N}-\text { free }+0 \cdot 01 \mathrm{~N}- \\
\mathrm{NH}_{4} \text { tartrate }\end{array}$ & $\left.\begin{array}{l}1 \cdot 3 \\
1 \cdot 6\end{array}\right\}$ & $\left.\begin{array}{l}64 \\
66\end{array}\right\}$ & $70 \pm 6 \ddagger$ \\
\hline & UV 17 & $\begin{array}{l}\mathrm{N} \text {-free }+0.01 \mathrm{~N}- \\
\mathrm{NH}_{4} \text { tartrate }+ \\
0.01 \text { M-glutamic acid* }\end{array}$ & $\left.\begin{array}{l}2 \cdot 5 \\
2 \cdot 1\end{array}\right\}$ & $\left.\begin{array}{l}21 \\
20\end{array}\right\}$ & $65 \pm 5 \ddagger$ \\
\hline \multirow[t]{2}{*}{$\mathbf{5}$} & UV21-W\$ & $\begin{array}{l}\mathrm{N} \text {-free }+0.02 \mathrm{~N}- \\
\mathrm{NH}_{4} \text { tartrate }\end{array}$ & $1 \cdot 4$ & 103 & 100 \\
\hline & $\begin{array}{l}\text { alf-neutral } \\
\text { uplicate ct } \\
\text { stimates of } \\
\text { ild type d }\end{array}$ & $\begin{array}{l}\text { ed with } \mathrm{NaOH} \text {. } \\
\text { ures. } \\
\text { uclear ratio based on } \\
\text { ived by back-mutatio }\end{array}$ & $\begin{array}{l}\text { abined } \\
\text { am. }\end{array}$ & & 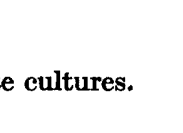 \\
\hline
\end{tabular}

\section{Production of other enzymes by the mutant}

The standard mutant strain and the derived back-mutant strain UV 21-W, which should be virtually isogenic except for the locus under study, were compared for their production of other enzymes related in substrate specificity to glutamic dehydrogenase. The enzymes tested for were: isocitric acid and glucose-6-phosphate dehydrogenases (both specific for TPN); transaminases catalysing transfer of amino groups from L-alanine, L-aspartic acid, L-ornithine, L-phenylalanine and L-valine respectively to $\alpha$-ketoglutarate. Evidence to be published later indicates that at least 4 different enzymes are involved in these five transaminase reactions. The two strains were grown for $48 \mathrm{hr}$. on $\mathrm{N}$-free medium supplemented with $0.01 \mathrm{M}$-glutamic acid (half-neutralized with $\mathrm{NaOH}$ ) and $0.01 \mathrm{~N}$-ammonium tartrate.

For the assay of the two dehydrogenases extracts were prepared as for the assay of glutamic dehydrogenase, and the enzyme activities were determined by measuring the increase in rate of reduction of TPN in a spectrophotometer 
cell following addition of substrate. Isocitric dehydrogenase activity was increased nearly threefold by manganese ions. The results are given in Table 3. It will be seen that the levels of these two enzymes are similar in mutant and wild-type.

Table 3. Glucose-6-phosphate and isocitric dehydrogenase activities in wild type and mutant

\begin{tabular}{|c|c|c|}
\hline \multirow[b]{2}{*}{ Assay system } & \multicolumn{2}{|c|}{ Activity $\left(\Delta \mathbf{E}_{340} / \mathrm{min} . / \mathrm{mg}\right.$. protein $\left.\times 10^{3}\right) \dagger$} \\
\hline & Mutant (am) & Wild-type (UV21-W) \\
\hline $\begin{array}{l}1 \mathrm{ml} \text {. extract, } 1 \mathrm{ml} \text {. TPN in buffer;* } \\
0.2 \mathrm{ml} .0 \cdot 1 \mathrm{M} \text {-hexose-6-phosphate added } \\
\text { after measuring initial rate of re- } \\
\text { duction }\end{array}$ & 270 & 230 \\
\hline $\begin{array}{l}\text { After complete reduction of TPN by } \\
\text { above system, } 5 \mu \text { mole } \alpha \text {-ketoglu- } \\
\text { tarate and } 10 \mu \text { mole } \mathrm{NH}_{4} \mathrm{Cl} \text { added, } \\
\text { initial rate of reoxidation taken as } \\
\text { measure of glutamic dehydrogenase }\end{array}$ & $\mathbf{0}$ & c. 90 \\
\hline $\begin{array}{l}1 \mathrm{ml} \text {. extract, } 0 \cdot 25 \mathrm{ml} .0 \cdot 0067 \mathrm{M}-\mathrm{MnCl}_{2} \text {, } \\
1 \mathrm{ml} \text {. TPN in buffer; } * 0 \cdot 1 \mathrm{ml} .0 \cdot 1 \mathrm{M}- \\
\text { DL-isocitrate added after measuring } \\
\text { initial rate of reduction }\end{array}$ & 120 & 110 \\
\hline
\end{tabular}

* $0.05 \%$ TPN (31 \% pure) in phosphate buffer.

$\uparrow$ Activities corrected for slow TPN reduction in the absence of added substrate.

Extracts for assay of transaminases were prepared by grinding washed and blotted pads of mycelium with powdered glass and 2.5 vol. of pre-chilled phosphate buffer in an ice-cooled mortar for $15 \mathrm{~min}$. followed by centrifugation at $2700 \mathrm{~g}$ for $5 \mathrm{~min}$. The supernatants were dialysed against three changes of buffer at $0-5^{\circ}$ for $3 \mathrm{hr}$. The transaminase activities were almost identical in the two strains compared on the basis of wet weight of mycelium, but on the basis of protein content the activities were all rather less in the mutant (Table 4). The mutant extract was much more turbid than the wild-type extract, and

\section{Table 4. Transaminase activities in wild type and mutant}

In each digest: $0.3 \mathrm{ml}$. extract in phosphate buffer, $15 \mu$ mole $\mathrm{Na} \alpha$-ketoglutarate, $15 \mu$ mole $\mathrm{L}$-amino acid or water as control in a total vol. of $0.6 \mathrm{ml}$. Glutamate formation in water controls subtracted. Incubation at $34^{\circ}$ for $15 \mathrm{~min}$. for alanine and aspartate digests and for $60 \mathrm{~min}$. for the others.

Wet wt. mycelium (g.)

Extracted in (ml.)

Amino acid

Alanine

Aspartic acid (Na salt)

Ornithine

Valine

Phenylalanine

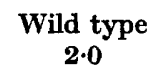

$5 \cdot 0$

$\mu$ mole glutamate formed

$\begin{array}{cccc}\text { Total } & \begin{array}{c}\text { Per mg. } \\ \text { protein }\end{array} & \text { Total } & \begin{array}{c}\text { Per mg. } \\ \text { protein }\end{array} \\ 3.2 & 0.74 & 3.6 & 0.51 \\ 1.4 & 0.32 & 1.5 & 0.21 \\ 1.6 & 0.37 & 1.8 & 0.26 \\ 1.2 & 0.28 & 1.1 & 0.16 \\ 0.8 & 0.18 & 0.7 & 0.10\end{array}$

Mutant

$2 \cdot 1$

$\mathbf{5} \cdot \mathbf{2}$ 
it may be that a higher proportion of protein of the mutant extract was associated with particles, the transaminases being in the soluble fraction (Fincham, 1951 b). Other experiments in which glutamate formation was estimated semi-quantitatively by visual inspection of chromatograms (Fincham, 1953) revealed no consistent differences between mutant and wildtype in respect of transaminase activities.

\section{DISCUSSION}

The conclusion to be drawn from these experiments is that, in this case, the mutation of a single gene prevents the formation of a single enzyme. The experiments on enzyme production by heterocaryons make it seem likely that the mutation acts by removing part of the enzyme-producing system rather than by inhibiting or diverting the activity of a system with which the gene in question is not normally directly involved, since there is no clear indication of any suppression by mutant nuclei of enzyme production in the heterocaryons. Although it is not completely recessive in heterocaryons, the mutant allele, in Muller's (1932) terminology, seems to be an amorph rather than an antimorph. This conclusion would be strengthened if wild-type and mutant alleles could be obtained in the same nucleus.

The mutation seems to be specific in its effect, affecting only one enzyme activity out of eight examined. Isocitric dehydrogenase, glutamic dehydrogenase and the transaminases probably normally act in sequence in producing, aminating and regenerating $\alpha$-ketoglutaric acid; the mutation has the effect of removing one step in the sequence without affecting the others.

It would be of great interest to know whether there is only one locus at which mutation has this effect. There is little information on this other than the fact that only two such mutations have been discovered among several thousand biochemical mutants and these are almost certainly allelic (J. A. Pateman, unpublished). A rather complicated situation has been uncovered by Yanofsky (1953) in the possibly parallel case of mutational elimination of tryptophan desmolase. Yanofsky obtained twenty-two mutants which were all alike in lacking tryptophan desmolase, and he also found three 'suppressor' mutations at different loci which restored the enzyme when combined with some of the mutants but not with others, and which differed among themselves in the mutants which they could suppress. The meaning of these observations is not clear, but if all twenty-two mutations are allelic a rather specific relation between a single locus and tryptophan desmolase production would seem to be indicated. The fact that some of the mutants were 'suppressable' may be taken to imply that they represent some alteration of the gene short of irreparable inactivation so that some (though never completely normal) activity can be restored by alteration of conditions in the cell as, for instance, by gene mutation of various kinds. It will be of considerable interest to see whether a similar situation exists in the present case.

Little can be said regarding the role of the gene in enzyme production. To speak of gene 'control' of enzyme synthesis may be misleading unless it is realized that the most that can be shown by present methods is that the wild 
type gene is an essential component of the enzyme-producing mechanism. Other components, including perhaps other genes or even cytoplasmic 'selfduplicating' units (Ephrussi, 1953), are by no means excluded. In the present case the concentration of enzyme is dependent, most strikingly, on the genotype, but also to some extent on conditions of growth. This may suggest that some kind of gene product, the concentration of which may vary, rather than the gene itself is directly involved in enzyme synthesis.

Part of this investigation was aided by a grant from the Nuffield Foundation. My thanks are also due to Dr B. C. Loughman for hexose-6-phosphate, to $\mathrm{Mr}$ J. A. Pateman for the use of some of his strains and unpublished data, and to Miss M. Haycock for technical assistance.

\section{REFERENCES}

Cons, M. \& Monod, J. (1953). Specific induction and inhibition of enzyme biosynthesis. In Adaptation in Micro-organisms. Symp. Soc. gen. Microbiol. 3, 132.

Ephrussi, B. (1953). Nucleo-Cytoplasmic Relations in Micro-organisms. Oxford: Clarendon Press.

Evans, H. J. \& Nason, A. (1953). Pyridine nucleotide-nitrate reductase from extracts of higher plants. Plant Physiol. 28, 233.

Fincham, J. R. S. (1950). Mutant strains of Neurospora deficient in aminating ability. J. biol. Chem. 182, 61 .

Fincham, J. R. S. (1951 $a)$. The occurrence of glutamic dehydrogenase in Neurospora and its apparent absence in certain mutant strains. J. gen. Microbiol. $5,793$.

Fincham, J. R. S. (1951 b). Transaminases in Neurospora crassa. Nature, Lond. 168, 957.

Fincham, J. R. S. (1953). Ornithine transaminase in Neurospora and its relation to the biosynthesis of proline. Biochem J. 53, 313.

FowDEN, L. (1951). The quantitative recovery and colorimetric estimation of amino acids separated by chromatography. Biochem. J. 48, 327.

LePage, G. A. \& Mueller, G. C. (1949). Preparation of TPN. J. biol. Chem. 180, 975.

Muller, H. J. (1932). Further studies on the nature and causes of gene mutation. Proc. 6th Int. Conf. Genet. 1, 213.

RYan, F. J., Beadle, G. W. \& TATUm, E. L. (1943). The tube method of measuring the growth rate of Neurospora. Amer. J. Bot. 30, 784.

StickLaNd, L. H. (1951). The determination of small quantities of bacteria by means of the biuret reaction. J. gen. Microbiol. 5, 698.

Tissiéres, A., Mitchell, H. K. \& Haskins, F. A. (1953). Studies on the respiratory system of the poky strains of Neurospora. J. biol. Chem. 205, 423.

Umbreit, W. W., Burris, R. H. \& Stauffer, J. F. (1949). Manometric Methods and Tissue Metabolism. Minneapolis: Burgess Publishing Co.

Westergaard, M. \& Mrtchell, H. K. (1947). Neurospora. V. A. synthetic medium favouring sexual reproduction. Amer. J. Bot. 34, 573.

YANOFSKY, C. (1953). Further studies with the $t d$ mutants of Neurospora. Genetics, 38, 702. (Abstr.) 

Journal of General Microbic'ogy, Vol. 11, No. 2

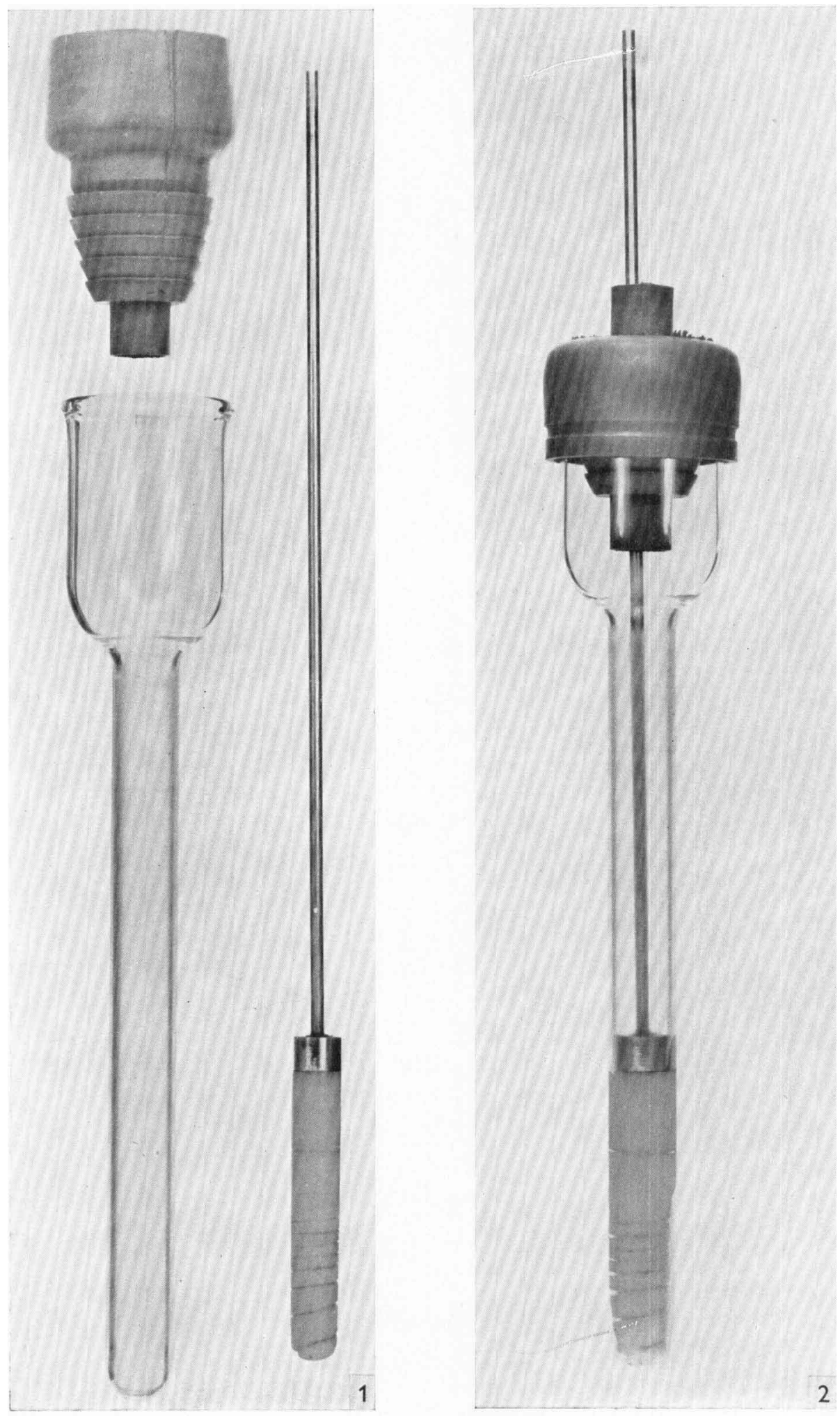

G. R. F. Hilson \& S. D. Elek-Nylon tissue grinder. Plate 1 